\title{
Advances in Chickpea Genomic Resources for Accelerating the Crop Improvement
}

\author{
Manish Roorkiwal, Ankit Jain, Mahendar Thudi \\ and Rajeev K. Varshney
}

\begin{abstract}
Chickpea plays a major role in food and nutritional security worldwide. Its productivity is severely affected by various biotic and abiotic stresses; hence development of stress resilience varieties that can yield higher under stress environment remains the call of the hour. Conventional breeding approaches clubbed with the genome information, commonly known as genomic-assisted breeding (GAB) have the potential to accelerate the crop improvement efforts. In order to deploy the GAB for crop improvement in chickpea, there was need to convert an orphan crop chickpea into the genomic resource-rich crop. Advent of sequencing technology has resulted in reduction of cost and led to development of huge genomic resources in chickpea. A variety of markers have been developed, used for various mapping studies including linkage mapping and association mapping and finally deployed for developing the superior varieties using GAB approached such as marker assisted backcrossing and genomic selection. The chapter reviews the journey of chickpea status from orphan crop with almost no marker resources to a genome resource-rich crop, which are being used for achieving the genetic gains at a momentum.
\end{abstract}

M. Roorkiwal $(\bowtie) \cdot$ A. Jain $\cdot$ M. Thudi · R.K. Varshney International Crops Research Institute for the Semi-Arid Tropics (ICRISAT), Patancheru, India e-mail: m.roorkiwal@cgiar.org

\subsection{Introduction}

Chickpea (Cicer arietinum L.) is the second most important food legume with 13.98 million hectares under cultivation across 55 different countries worldwide (FAO 2014). Chickpea is a self-pollinated diploid $(2 n=16)$ annual crop with genome size of $\sim 740 \mathrm{Mbp}$ (Varshney et al. 2013a). It is commonly known as gram, Bengal gram or garbanzo bean, mostly grown in arid and semiarid regions, predominantly in developing 
countries (90\% of its cultivated area) (Croser et al. 2003). Chickpea is a valuable source for many important proteins, minerals, and vitamins among legumes and contributes as an important source for protein for vegetarian diet. Chickpea has one of the most balanced nutritional compositions, and its protein digestibility is the best among the cool season food legumes. Apart from human consumption, chickpea also has economic importance in animal feed as well as in herbal medicine.

Ecologically, chickpea is known as an efficient $\mathrm{N}_{2}$-fixing system due to its capability of symbiotic nitrogen fixation and, therefore, fits well in crop rotation programs. Nearly, $90 \%$ of the crop is cultivated under rainfed condition, mostly surviving on receding soil moisture. Current global yield average of chickpea is $0.9 \mathrm{t} / \mathrm{ha}$ (FAO 2014), much lower than its estimated potential of $6 \mathrm{t} / \mathrm{ha}$ under optimum growing conditions (Singh 1985). Chickpea productivity is adversely affected by various biotic and abiotic stresses like Ascochyta blight (AB caused by Ascochyta rabiei), Fusarium wilt (FW caused by Fusarium oxysporum f. sp. ciceris), pod borer (Helicoverpa armigera), Botrytis gray mold (BGM), drought, and cold (Ruelland et al. 2002). Three major abiotic stresses responsible for reduction in seed yield in chickpea include drought, heat, and cold (Singh 1985; Singh et al. 1997). However, drought stands to be the major challenge in chickpea growing regions, causing a $40-50 \%$ reduction in yield globally (Ahmad et al. 2005).

Like every extensively cultivated crop, chickpea is also facing the consequences of the continuously deteriorating environmental conditions, i.e., more rigorous temperature regimes and dry soils (abiotic stress). Many physiological processes associated with crop growth and development are reported to be influenced by water deficits (Turner and Begg 1978). To counter this global phenomenon, extensive artificial irrigation is required to achieve acceptable harvest yield in many of the chickpea cultivating regions (Bakht et al. 2006). However, in the long term this practice results in increased soil salinization and therefore contributing toward declining productivity. Considering the effect of various stresses on yield, it is very important to initiate serious efforts in the direction of developing improved varieties or alternate strategies that allow sustainable chickpea production under adverse environmental conditions. Application of available approaches to improve crop productivity under adverse environmental conditions requires a better understanding of the mechanisms involved in crop's response to such stresses. Plant stress responses are generally controlled by a network of specialized genes through intricate regulation by specific transcription factors (Chen and Zhu 2004). Thus, the application of a holistic approach combining genomics with breeding and physiology, termed as genomics-assisted breeding (GAB) (Varshney et al. 2005), provides strategies for improving component traits of drought tolerance that should prove more effective and efficient than the conventional methods (Mir et al. 2012).

Until last decade, chickpea was known as an "orphan crop" due to availability of limited genomic resources and hence inclination was much more toward conventional breeding approaches to increase yield (Varshney et al. 2012a). In order to generate genomic resources and deploy them for developing superior chickpea varieties using modern breeding approaches, efforts were initiated and significant progress has been made in the recent past. Using the advent of next generation sequencing (NGS) technologies, large-scale molecular markers have been developed recently. These resources have been used for constructing dense genetic maps and identification of various markers associated with traits of interest (Varshney et al. 2012b, 2015; Varshney 2016).

The chapter describes about the efforts to develop the genomic resources and deployment of these resources in breeding for enhancing the rate of genetic gain in chickpea.

\subsection{Genomic Resources}

Efforts to improve chickpea productivity using conventional approaches were able to enhance the yield but could not achieve the desired results 


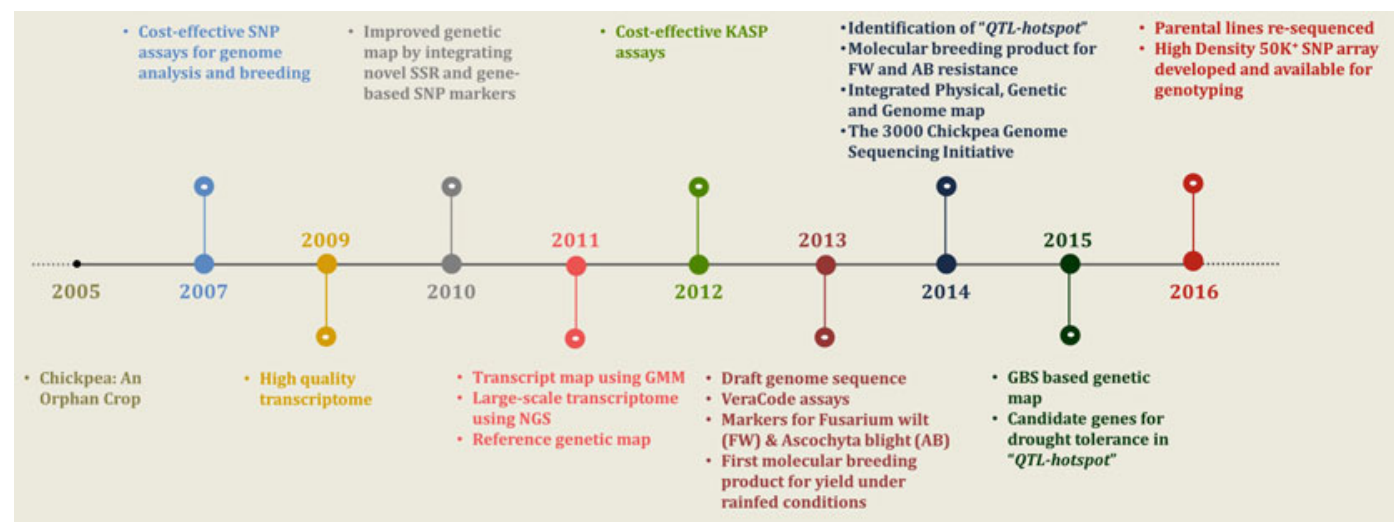

Fig. 6.1 Account of the significant accomplishments made in the field of development of genomic resources and their deployment in chickpea crop improvement

due to narrow genetic base in cultivated chickpea. Efforts at international platform were initiated to develop genomic resources. ICRISAT along with its partners accelerated the development of these genomic resources during the last few years (Fig. 6.1). These genomic resources have also been deployed in breeding using GAB and have already started to make an impact on chickpea improvement (Pandey et al. 2016). A brief update on development of different type of markers has been given below:

Isozyme markers: Isozymes are multiple forms of enzyme that differ in amino acid sequence but control different chemical reaction based on different kinetic parameters or regulatory properties. Isozymes are the form of biochemical/molecular markers that are based on the staining of proteins with identical functions with different electrophoretic movement. In the case of chickpea, isozyme markers were developed and their segregation was observed in the $\mathrm{F}_{2}$ population derived from interspecific crosses of Cicer arietinum L. with $C$. reticulatum Lad. and C. echinospermum (Gaur and Slinkard 1990a, b). Based on isozyme profile of nine annual and one perennial species of chickpea, Kazan and Muehlbauer (1991) classified the species into four groups which was later supported by several studies (Ahmad et al. 1992; Labdi et al. 1996; Tayyar and Waines 1996). Kazan et al. (1993) with application of morphological and isozyme markers on several $\mathrm{F}_{2}$ families supported similar mode of inheritance as obtained using morphological markers in previous studies. Low level of polymorphism was observed in most of the isozymes-based studies in the cultivated chickpea (Oram et al. 1987; Gaur and Slinkard 1990b; Ahmad et al. 1992; Kusmenoglu et al. 1992; Van Rheenen 1992; Labdi et al. 1996; Tayyar and Waines 1996).

Restriction Fragment Length Polymorphism (RFLP) and Randomly Amplified Polymorphic DNA (RAPD) markers: RFLP uses difference in homologous DNA sequences that can be detected by the presence of fragments of different lengths after digestion of the DNA samples. RFLP includes digestion of DNA sample using restriction enzymes and separation of restriction fragments by gel electrophoresis and then hybridization with genomic DNA/cDNA probes. Subsequently, hybridization pattern is observed on x-ray film and polymorphism obtained in different banding patterns due to change in the restriction enzyme recognition site. RAPD includes differential PCR amplification of a fragment of DNAs from short oligonucleotide sequences. RAPD does not require prior sequence information, and random identical 10-mer primers are used to amplify a segment of DNA, depending on positions that are complementary to the primers' sequence.

In order to assess the polymorphism existing between desi- and kabuli-type chickpea cultivars, RFLP markers were used (Udupa et al. 
1993). In another study, RFLP analysis on cultivated chickpea accessions from 11 different countries indicated three major center of diversity Pakistan-Afghanistan, Iraq-Turkey and Lebanon, and India being known as secondary center of genetic diversity previously showed lower diversity than above (Serret et al. 1997).

Furthermore, using RFLP, isozyme, and RAPD markers, an integrated genetic linkage map consisting 27 isozyme, 10 RFLP, and 45 RAPD marker loci covering $550 \mathrm{cM}$ was developed in chickpea using interspecific crosses of cultivated chickpea and a closely related wild species (C. reticulatum) (Simon and Muehibauer 1997). In another study, RFLP and RAPD markers were used to assess the polymorphism in chickpea accessions including some of the mutants (Banerjee et al. 1999). RAPD markers were also used to identify the markers associated with fusarium resistance against race 1 and 4 using C $104 \times$ WR 315 cross (Tullu et al. 1998). Another study using RAPD and oligonucleotide probes to assess genetic diversity among 29 elite Indian chickpea cultivars indicated narrow genetic base in chickpea (Sant et al. 1999). Similarly, genetic diversity and phylogenetic analysis across 75 chickpea accessions using 12 RAPD primer resulted in 234 polymorphic fragments (Iruela et al. 2002). Another study from Singh et al. (2003), where of 78 RAPD primers, 20 primers were found polymorphic, continues to uphold the previous hypothesis about narrow genetic base.

Amplified Fragment Length Polymorphis (AFLP): AFLP marker system effectively combines principles of both RFLP and RAPD in order to produce reproducible results (Vos et al. 1995). Genomic fragmented generated as a result of restriction digestion is ligated with primer-recognition sequences (adaptors). Selective PCR amplification of these restriction fragments using a limited set of labeled primers is separated on gel/capillaries electrophoresis. AFLP markers were utilized in assessing the genetic diversity, delineating the phylogeny of chickpea germplasm (Nguyen et al. 2004; Sudupak et al. 2004; Shan et al. 2005; Talebi et al. 2008) and construction of genetic linkage map (Winter et al. 2000).

Simple Sequence Repeat (SSR) and SNP markers: SSR (microsatellite) markers being multi-allelic and codominant in nature and SNPs owing to their greater abundance in the genome and their amenability for high-throughput genome analysis are extensively used for several genomics applications (See Varshney et al. 2007a; Singh et al. 2008; Pandey et al. 2016).

In the case of chickpea, microsatellite markers developed to date employed one of the following approaches: (i) probing the genomic libraries with oligonucleotide repeats, (ii) sequencing of microsatellite-enriched libraries, and (iii) sequencing of bacterial artificial chromosome (BAC) clones. Initially, 16 SSRs were reported by screening small insert genomic libraries with di-, tri-, and tetra oligonucleotide repeat probes to identify SSR repeats (Hüttel et al. 1999) and subsequently 174 SSRs were reported by screening size select genomic DNA libraries (Winter et al. 1999). In subsequent years, both BAC and BIBAC libraries were used for developing SSR markers by Lichtenzveig et al. (2005). In addition, as a result of concerted efforts at ICRISAT, a large number of SSR markers were developed from microsatellite-enriched libraries and bacterial artificial chromosome (BAC) clones ICC 4958 to report 311 novel SSRs (Nayak et al. 2010). Another effort by Thudi et al. (2011) sequenced 55,680 BAC clones and identified 6845 SSR motifs and designed primers for 1344 SSRs.

Further, during recent years efforts were also made to understand the transcriptomes, gene expression profiles in various stressed plant tissues and stress responsive expressed sequence tags (ESTs) were used for candidate gene identification and develop functional markers for breeding applications. For instance, initial efforts to develop functional markers from expressed sequence tags, were made in 2005 (Buhariwalla et al. 2005). Drought and salinity responsive ESTs were used to develop 177 new EST-SSRs (Varshney et al. 2009). Similarly, several studies provided the insights into global view of transcriptome dynamics of different stress responsive 
tissues (Hiremath et al. 2011; Garg et al. 2011a, b; Singh et al. 2013; Afonso-Grunz et al. 2014; Kudapa et al. 2014). Consequently, shift to study transcriptomics led to sequencing of EST libraries and resulted in flooding of EST sequences in public domains. In order to utilize the generated data efficiently and develop functional markers, screening of genic data for SSRs led to development of EST-SSR markers (Kottapalli et al. 2009; Gupta et al. 2015; Khajuria et al. 2015).

SNP markers have also become popular because of their genome-wide abundance and possibility of cost-effective high-throughput genotyping. Using in silico approaches, 184 putative SNPs were identified in 19 contigs constructed with 1499 ESTs generated from different Cicer species available in public domain (Varshney et al. 2007b). In addition, recent advances in NGS technologies enabled the generation of huge amount of sequencing data in very less time at very low cost (Thudi et al. 2012). In the case of chickpea, using Sanger sequencing technology more than 20,000 expressed sequence tags (ESTs) were generated from drought and salinity stress-challenged tissues (Varshney et al. 2009). In addition to these ESTs, NGS technologies were used for generating additional sequencing data on $>20$ tissues representing different developmental stages (Hiremath et al. 2011). Combined data analysis using Sanger ESTs and NGS transcripts led to generation of first transcript assembly with 103,215 tentative unique sequences (TUSs) (Hiremath et al. 2011). Analysis of these ESTs and transcript assemblies led to identification of few thousand SNPs. In addition, other sequencing approaches including Illumina sequencing of parental lines of chickpea mapping populations have identified several thousand SNPs (Hiremath et al. 2011). Similarly, allele-specific sequencing on chickpea genotypes has led to identification of $\sim 2000$ SNPs (Gujaria et al. 2011; Roorkiwal et al. 2014a). Deokar et al. (2014) have also reported 51,632 genic SNPs identified by 454 transcriptome sequencing of $C$. arietinum and $C$. reticulatum genotypes. Using genomic and transcriptomic SNPs, Gaur et al. (2015) mapped 6698 SNPs on eight linkage group spanning $1083.93 \mathrm{cM}$ for interspecific RIL population. Verma et al. (2015) used genotyping by sequencing (GBS) for genotyping of intraspecific RIL population contrasting for seed traits.

Diversity Array Technology (DArT) markers: In addition to SSRs and SNPs, another marker system, DArT, has been widely used for construction of genetic maps and diversity analysis. DArT markers were marker of choice in the absence of enough genomic resources for constructing dense genetic maps and were widely used for Triticeae species (Neumann et al. 2011). Therefore, ICRISAT in collaboration with DArT Pty Ltd developed the DArT arrays with 15,360 clones (Thudi et al. 2011). Similar to other marker systems, DArT arrays also showed narrow genetic diversity in cultivated gene pool as compared to wild species (Roorkiwal et al. 2014b). By combining genotyping, data generated using DArTseq platform for 3000 polymorphic markers for a set of 320 chickpea lines, with multilocation phenotyping data Roorkiwal et al. (2016), estimated prediction accuracies and hence made the first attempt toward genomic selection (GS) studies.

Sequencing-based marker systems: NGS technologies offer the ability to produce huge sequence data sets at relatively low cost in less time. Availability of these low-cost sequencing technologies has enabled to map the target traits at sequencing level and replacing the traditional trait mapping approaches by sequence-based trait mapping. Sequencing technologies such as GBS, skim sequencing, and whole genome re-sequencing (WGRS) provide genome-wide large-scale marker information for highresolution trait mapping (Pandey et al. 2016). In the case of chickpea, GBS has been used for refining the "QTL-hotspot" identified an intraspecific cross (ICC $4958 \times$ ICC 1882) (Jaganathan et al. 2015). Similarly, Kale et al. (2015) used skim sequencing approach to genotype RIL population (ICC $4958 \times$ ICC 1882) and led to identification of 84,963 SNPs, 
out of which $76.01 \%$ were distributed over the 8 pseudomolecules. Similarly, Kujur et al. (2015) and Bajaj et al. (2015) identified $>40,000$ and $>80,000$ high-quality genome-wide SNPs using integrated reference genome- and de novo-based GBS approach from 93 wild and cultivated chickpea accessions, respectively. With the availability of large-scale SNP marker information, one of the major challenges was to use these markers routinely in breeding programs. Utilization of any marker system in breeding application is largely affected by the possibility of automation, time for data turnaround, and cost. Different approaches for deploying markers in breeding require variable number of markers, and therefore a range of genotyping platforms/systems are required. In the case of chickpea, different SNP genotyping platforms were developed to meet all needs. For instance, GoldenGate and VeraCode assays were developed in chickpea for genotyping reference set consisting of 288 of genotype with 96 SNPs (Roorkiwal et al. 2013). However, in many breeding applications, only few SNPs are required to genotype large population where GoldenGate and VeraCode assays may not be cost effective. For such applications, more than 2000 KASP markers were developed for chickpea (Hiremath et al. 2012).

High-density genotyping arrays: With the advent of low-cost NGS technologies, large-scale re-sequencing projects have been initiated and resulting in availability of millions of SNP markers in several crop plants. In order to use these ever expanding genome resources in the breeding applications, there is a need for low-cost, high-throughput genotyping platforms. Recent developments in the arrays technology have brought down the cost of high-throughput genotyping, thus making it accessible to most of the researchers and breeding communities. SNP genotyping platforms can be used for genetic diversity studies, fine mapping, association mapping, GS, and evolutionary studies. In order to exploit the available millions of SNP markers in chickpea for breeding application, efforts to develop a high-throughput SNP genotyping platform were initiated. As set of 70,463 high quality non redundant SNPs were selected using an assortment of the criterion from a pool of 4.9 million SNPs. Based on p-convert score, a set of 61,174 SNPs was selected of which 50,590 SNPs were tiled on Affymetrix Axiom array (Roorkiwal et al. 2017). These arrays are being used for genotyping breeding material and RIL population for high-resolution genetic mapping and breeding applications.

\subsection{Draft Genome and Re-sequencing Efforts}

Draft genome sequence serves as a base for better understanding of plants response mechanism and genetic basis for gene function. In addition, draft genome also helps for identification of large-scale markers. Reduced incurring cost of NGS and huge data output allows researcher to tap the variation prevailing in whole genome. Considering the utility of genome sequence, ICRISAT led International Chickpea Genome Sequencing Consortium (ICGSC) decoded the chickpea genome sequence. Illumina sequencing was used to sequence CDC Frontier, a kabuli chickpea variety, and $\sim 153 \mathrm{~Gb}$ raw sequence data was generated. After the data cleaning, $87.65 \mathrm{~Gb}$ high-quality sequence data was used to assemble $544.73 \mathrm{Mb}$ of genome, representing $74 \%$ of chickpea genome (Varshney et al. 2013a). In addition to draft genome, ICGSC also undertook re-sequencing of 90 cultivated and wild chickpea accessions using NGS-based whole genome re-sequencing and restriction site-associated DNA (RAD) technology (Varshney et al. 2013a).

In parallel, another effort to sequence chickpea genome targeted ICC 4958, a desi chickpea genotype for developing the draft chickpea genome assembly. NGS technology along with bacterial artificial chromosome end sequencing was used to assemble $\sim 520 \mathrm{Mb}$ of chickpea genome (Jain et al. 2013). Recently, Gupta et al. (2016) developed the draft assembly of PI 489777 that resulted in $416 \mathrm{Mb}$ draft genome of wild progenitor and $78 \%(327 \mathrm{Mb})$ of this assembly could be anchored to eight linkage groups. 
Development of the draft genome assembly has been followed with efforts to improve the assemblies. Individual chromosome from both desi and kabuli varieties was isolated and sequenced using NGS-based sequencing technology to validate the desi and kabuli assemblies. Chromosomal sequencing approach could identify small misassembled region in kabuli; however, in desi a large region was found to be misassembled (Ruperao et al. 2014). In a similar manner to improve the desi assembly, Parween et al. (2015) generated additional sequence data and reported an improved assembly of ICC 4958 with 2.7-fold increase in length of pseudomolecules.

With an objective to exploit the germplasm wealth stored in genebank for identification of novel alleles and genetic variations, large-scale re-sequencing efforts were initiated. Large-scale germplasm resources available in genebanks provide the opportunity to address the issue of low genetic diversity (McCouch et al. 2013). Illumina HiSeq 2500 was used for re-sequencing 100 chickpea varieties released across 14 countries in last five decades. Re-sequencing data on these 100 elite varieties along with 29 earlier re-sequenced line was used for understanding the impact of breeding on genetic diversity and gain insights into temporal trends in chickpea diversity (Thudi et al. 2016). Re-sequencing data on 100 elite chickpea varieties was used for developing first-generation HapMap of chickpea. In parallel, 300 lines from chickpea reference set were also re-sequenced using whole genome re-sequencing approach. A total of $1.8 \mathrm{~Tb}$ raw sequence data was generated and used for aligning against reference chickpea genome to identify 4.9 million SNPs (unpublished). Re-sequencing data on 300 chickpea lines from reference set along with multi-season, multilocation phenotyping data was used for GWAS analysis for identification of markers associated with trait of interest. Very recently, ICRISAT has launched "The 3000 Chickpea Genome Sequencing Initiative" where 3000 lines from the global composite collection of chickpea from genebanks of ICRISAT and ICARDA will be re-sequenced for identification of novel alleles (Varshney 2016)".

\section{Genetic Maps and Trait Mapping}

In order to use available genomic resources for modern breeding approaches effectively, first step is to identify the markers associated with trait of interest. For identification of markers associated with trait of interest, mainly two approaches are used, namely (i) biparental mapping population-based linkage mapping and (ii) germplasm-based genome-wide association mapping (GWAS). For linkage mapping-based identification of markers associated with trait of interest, first step is to develop the genetic maps.

Beginning with the morphological markers to the next generation of markers that include DArT, SNPs, etc., wide range of marker systems have been used to generate genetic map for chickpea. Most of the genetic maps developed till date have been described in Table 6.1, and it also shows the evolution of marker system over the course of time. Current section describes some of the recently developed genetic maps briefly. Thudi et al (2011) reported a high-density genetic map developed using the interspecific mapping population (ICC $4958 \times$ PI 489777) with 1291 loci spanning across a distance of $845.56 \mathrm{cM}$ on eight linkage groups. In parallel, another effort by Choudhary et al. (2012) developed an advanced gene-rich map with 406 loci for the same population. In addition, two intraspecific mapping populations (ICC $4958 \times$ ICC 1882 and ICC $283 \times$ ICC 8261) segregating for drought tolerance-related root traits were also used for generation of genetic maps with comprising 241 loci and 168 loci, respectively, and a consensus genetic map comprising 352 loci was also constructed. Using extensive phenotyping, data QTL analysis was performed and 45 robust main-effect QTLs (M-QTLs) explaining up to $58.20 \%$ phenotypic variation were identified (Varshney et al. 2014a). In order to fine map these genetic maps, intraspecific mapping populations ICC $4958 \times$ 
Table 6.1 Various genetic linkage maps generated in chickpea

\begin{tabular}{|c|c|c|c|c|c|c|}
\hline $\begin{array}{l}\text { S. } \\
\text { No. }\end{array}$ & $\begin{array}{l}\text { Population } \\
\text { type }\end{array}$ & Marker type & $\begin{array}{l}\text { Markers/loci } \\
\text { mapped }\end{array}$ & $\begin{array}{l}\text { Linkage } \\
\text { groups }\end{array}$ & $\begin{array}{l}\text { Map distance } \\
(\mathrm{cM})\end{array}$ & References \\
\hline 1 & Intraspecific & $\begin{array}{l}\text { Morphological and isozyme } \\
\text { markers }\end{array}$ & 29 & 7 & 200 & $\begin{array}{l}\text { Gaur and } \\
\text { Slinkard } \\
(1990 a, b)\end{array}$ \\
\hline 2 & Interspecific & $\begin{array}{l}\text { Morphological and isozyme } \\
\text { markers }\end{array}$ & 28 & 8 & 257 & $\begin{array}{l}\text { Kazan et al. } \\
(1993)\end{array}$ \\
\hline 3 & Interspecific & $\begin{array}{l}\text { Morphological, isozyme, RFLP } \\
\text { and RAPD markers }\end{array}$ & 91 & 10 & 550 & $\begin{array}{l}\text { Simon and } \\
\text { Muehibauer } \\
\text { (1997) }\end{array}$ \\
\hline 4 & Interspecific & STMS markers & 120 & 11 & 613 & $\begin{array}{l}\text { Winter et al. } \\
\text { (1999) }\end{array}$ \\
\hline 5 & Interspecific & $\begin{array}{l}\text { RAPD, ISSR, isozyme and } \\
\text { morphological marker }\end{array}$ & 116 & 9 & 981.6 & $\begin{array}{l}\text { Santra et al. } \\
(2000)\end{array}$ \\
\hline 6 & Interspecific & $\begin{array}{l}\text { SSR, SAF, AFLP, ISSR, RAPD, } \\
\text { isozyme, cDNA, SCAR and } \\
\text { morphological markers }\end{array}$ & 303 & 16 & 2077.9 & $\begin{array}{l}\text { Winter et al. } \\
(2000)\end{array}$ \\
\hline 7 & Intraspecific & $\begin{array}{l}\text { STMS, RAPDs, ISSR and } \\
\text { morphological markers }\end{array}$ & 80 & 14 & 297.5 & $\begin{array}{l}\text { Cho et al. } \\
(2002)\end{array}$ \\
\hline 8 & Interspecific & $\begin{array}{l}55 \text { STMS and } 1 \text { RGA markers } \\
\text { integrated to Santra et al. (2000) }\end{array}$ & 167 & 9 & 1174.5 & $\begin{array}{l}\text { Tekeoglu } \\
\text { et al. (2002) }\end{array}$ \\
\hline 9 & Interspecific & $\begin{array}{l}\text { RAPD, ISSR, STMS and RGA } \\
\text { markers }\end{array}$ & 83 & 8 & 570 & $\begin{array}{l}\text { Collard et al. } \\
(2003)\end{array}$ \\
\hline 10 & Interspecific & $\begin{array}{l}47 \text { R gene-specific markers } \\
\text { integrated to Winter et al. (2000) }\end{array}$ & 296 & 12 & 2483.3 & $\begin{array}{l}\text { Pfaff and } \\
\text { Kahl (2003) }\end{array}$ \\
\hline \multirow[t]{3}{*}{11} & \multirow[t]{3}{*}{ Intraspecific } & \multirow{3}{*}{$\begin{array}{l}\text { STMS, RAPD, ISSR and } \\
\text { morphological markers }\end{array}$} & 125 & 11 & 33 & \multirow{3}{*}{$\begin{array}{l}\text { Cobos et al. } \\
(2005)\end{array}$} \\
\hline & & & 52 & 7 & 174.4 & \\
\hline & & & 138 & 10 & 427.9 & \\
\hline 12 & Intraspecific & $\begin{array}{l}\text { RAPD, ISSR, RGA, SSR and } \\
\text { ASAP markers }\end{array}$ & 230 & 8 & 739.6 & $\begin{array}{l}\text { Radhika } \\
\text { et al. (2007) }\end{array}$ \\
\hline 13 & Intraspecific & SSR and EST markers & 84 & 10 & 724.4 & $\begin{array}{l}\text { Kottapalli } \\
\text { et al. (2009) }\end{array}$ \\
\hline 14 & Interspecific & $\begin{array}{l}\text { STMS, RAPD, ISSR, } \\
\text { morphological and RGA markers }\end{array}$ & 169 & 8 & 751 & $\begin{array}{l}\text { Palomino } \\
\text { et al. (2009) }\end{array}$ \\
\hline 15 & Intraspecific & STMS markers & 33 & 8 & 471.1 & $\begin{array}{l}\text { Bharadwaj } \\
\text { et al. (2011) }\end{array}$ \\
\hline \multirow[t]{2}{*}{16} & \multirow[t]{2}{*}{ Interspecific } & \multirow[t]{2}{*}{ STMS and cross-genome markers } & 555 & 8 & 652.67 & \multirow{2}{*}{$\begin{array}{l}\text { Millan et al. } \\
(2010)\end{array}$} \\
\hline & & & 229 & 8 & 426.96 & \\
\hline 17 & Interspecific & $\begin{array}{l}52 \text { ICCM, } 46 \text { H-series SSR loci, } 71 \\
\text { gene-based and } 357 \text { legacy } \\
\text { markers }\end{array}$ & 521 & 8 & 2602.1 & $\begin{array}{l}\text { Nayak et al. } \\
(2010)\end{array}$ \\
\hline 18 & Intraspecific & STMS markers & 138 & 8 & 630.9 & $\begin{array}{l}\text { Gaur et al. } \\
\text { (2011) }\end{array}$ \\
\hline 19 & Interspecific & $\begin{array}{l}\text { SSR, CISR, CAPS, COS-SNP, } \\
\text { DArT, legacy markers }\end{array}$ & 1291 & & 845.56 & $\begin{array}{l}\text { Thudi et al. } \\
\text { (2011) }\end{array}$ \\
\hline
\end{tabular}


Table 6.1 (continued)

\begin{tabular}{|c|c|c|c|c|c|c|}
\hline $\begin{array}{l}\text { S. } \\
\text { No. }\end{array}$ & $\begin{array}{l}\text { Population } \\
\text { type }\end{array}$ & Marker type & $\begin{array}{l}\text { Markers/loci } \\
\text { mapped }\end{array}$ & $\begin{array}{l}\text { Linkage } \\
\text { groups }\end{array}$ & $\begin{array}{l}\text { Map distance } \\
(\mathrm{cM})\end{array}$ & References \\
\hline 20 & Interspecific & $\begin{array}{l}\text { EST-SSR, ITP, ESTP, MtEST, } \\
\text { gSSR and STMS markers }\end{array}$ & 406 & 8 & 1497.7 & $\begin{array}{l}\text { Choudhary } \\
\text { et al. (2012) }\end{array}$ \\
\hline 21 & Interspecific & $\begin{array}{l}\text { CKAM, TOG-SNP, GMM, } \\
\text { H-series, ICCM, CAM, SSR, } \\
\text { ISSR, SNaPshot assay-based SNP, } \\
\text { CAPS, DArT and RAPD markers }\end{array}$ & 1328 & 8 & 788.6 & $\begin{array}{l}\text { Hiremath } \\
\text { et al. (2012) }\end{array}$ \\
\hline 22 & Intraspecific & STMS, RAPD and ISSR markers & 57 & 8 & 379.47 & $\begin{array}{l}\text { Jamalabadi } \\
\text { et al. (2013) }\end{array}$ \\
\hline \multirow[t]{2}{*}{23} & \multirow[t]{2}{*}{ Intraspecific } & \multirow[t]{2}{*}{ SSR and SNP markers } & 464 & $\begin{array}{l}\text { Nine } \\
\text { LGs and } \\
\text { three } \\
\text { satellites }\end{array}$ & 658.7 & \multirow[t]{2}{*}{$\begin{array}{l}\text { Stephens } \\
\text { et al. (2013) }\end{array}$} \\
\hline & & & 408 & $\begin{array}{l}\text { Seven } \\
\text { LGs and } \\
\text { three } \\
\text { satellites }\end{array}$ & 752 & \\
\hline \multirow[t]{3}{*}{24} & \multirow[t]{3}{*}{ Intraspecific } & \multirow[t]{3}{*}{ SSRs, GMMs and DArT markers } & 241 & 8 & 621.51 & \multirow{3}{*}{$\begin{array}{l}\text { Varshney } \\
\text { et al. } \\
(2014 a, b, c)\end{array}$} \\
\hline & & & 168 & 8 & 533.06 & \\
\hline & & & 352 & 8 & 771.39 & \\
\hline 25 & Intraspecific & SSR markers & 23 & 4 & 690 & $\begin{array}{l}\text { Jingade and } \\
\text { Ravikumar } \\
(2015)\end{array}$ \\
\hline 26 & Interspecific & SNP markers & 6698 & 8 & 1083.93 & $\begin{array}{l}\text { Gaur et al. } \\
(2015)\end{array}$ \\
\hline 27 & Intraspecific & $\begin{array}{l}\text { EST-SSR, ITP, ESTP, and } \\
\text { genomic SSR markers }\end{array}$ & 131 & 8 & 1140.54 & $\begin{array}{l}\text { Gupta et al. } \\
(2015)\end{array}$ \\
\hline 28 & Intraspecific & SNP markers & 1007 & 8 & 727.29 & $\begin{array}{l}\text { Jaganathan } \\
\text { et al. (2015) }\end{array}$ \\
\hline 29 & Intraspecific & $\begin{array}{l}\text { RAPD, URP, STMS and } \\
\text { morphological markers }\end{array}$ & 33 & 7 & 285.3 & $\begin{array}{l}\text { Karami et al. } \\
(2015)\end{array}$ \\
\hline 30 & Interspecific & $\begin{array}{l}\text { Genic and genomic SSR, ITP and } \\
\text { SNP markers }\end{array}$ & 1697 & 8 & 1061.16 & $\begin{array}{l}\text { Khajuria } \\
\text { et al. (2015) }\end{array}$ \\
\hline 31 & Intraspecific & SNP markers & 3368 & 8 & 1006.98 & $\begin{array}{l}\text { Verma et al. } \\
(2015)\end{array}$ \\
\hline \multirow[t]{3}{*}{32} & \multirow[t]{3}{*}{ Interspecific } & \multirow[t]{3}{*}{ InDel markers } & 1059 & 8 & 978.21 & \multirow{3}{*}{$\begin{array}{l}\text { Srivastava } \\
\text { et al. (2016) }\end{array}$} \\
\hline & & & 594 & 8 & 603.26 & \\
\hline & & & 1479 & 8 & 978.61 & \\
\hline
\end{tabular}


ICC 1882 were genotyped using GBS approach and a high-density genetic map with 1007 marker loci spanning a distance of $727.29 \mathrm{cM}$ was developed (Jaganathan et al. 2015). In another effort for fine mapping, these two populations were genotyped using high-density Affymetrix SNP arrays "Axiom ${ }^{\circledR}$ CicerSNP array" and dense genetic maps with more than 13,000 and 7000 markers have been generated (Roorkiwal et al. 2017). Further, two candidate genomic regions responsible for salinity tolerance have been reported using ICCV $2 \times$ JG 11 derived RIL population (Pushpavalli et al. 2015).

In addition, two additional intraspecific mapping populations (C $214 \times \mathrm{WR} 315$ and $\mathrm{C}$ $214 \times$ ILC 3279) segregating for FW and AB were developed and used for QTL analysis. Two novel QTLs explaining 10.4-18.8\% phenotypic variation for FW and six QTLs explaining up to $31.9 \%$ of phenotypic variation for $\mathrm{AB}$ were identified (Sabbavarapu et al. 2013).

Further, several transcript maps have also been developed in chickpea. A transcript map with genic molecular markers including SNP, $\mathrm{SSR}$, and intron spanning region (ISR) markers has been developed on an interspecific mapping population (ICC $4958 \times$ PI 489777) (Gujaria et al 2011). In another effort to develop a second-generation transcript map, Hiremath et al. (2012) developed a genetic map comprising 1328 marker loci including 625 novel CKAMs, 314 TOG-SNPs, and 389 published marker loci with an average inter-marker distance of $0.59 \mathrm{cM}$.

A physical map based on finger printing of more than $70 \mathrm{~K}$ clones was developed for the reference genotype ICC 4958 (Varshney et al. 2014b). In addition to linkage mapping approach, efforts to map the markers using GWAS were able to identify several markers associated with traits of interest. Recently, Thudi et al. (2014) undertook a comprehensive association mapping analysis using whole genome scanning and candidate gene-based approach, which led to identification of 312 markers significantly associated with drought and heat response in chickpea. Another effort to map the markers using GWAS used the WGRS data on 300 lines from chickpea reference set and multi-season, multilocation phenotyping data for identification of several markers associated with yield and yield-related traits (unpublished). In summary, in addition to genetic maps for dissecting the complex traits, the integrated physical map with genome maps can be utilized for QTL cloning.

\subsection{Molecular Breeding}

With the availability of large-scale genomic resources and markers associated with trait of interest, next step is to use this information for accelerating the crop improvement program to enhance the rate of genetic gain. In chickpea efforts to use the markers in breeding have been focused on marker-assisted backcrossing (MABC) and now being shifted to GS. MABC has been successful for addressing the simple traits, while for addressing the complex traits where trait is controlled by several small effect QTLs, MABC is not that effective. GS approach using genome-wide marker profile has been suggested as a potential breeding approach for developing superior lines to address such complex traits (Meuwissen et al. 2001).

In chickpea, MABC efforts focused on introgression of QTL(s)/genomic region(s) responsible for yield under rainfed condition and disease resistance. As part of trait mapping, a genomic region on LG04 was identified as "QTL-hotspot" explaining up to $58 \%$ phenotypic variation for several root traits that control the yield under rainfed condition. Efforts to introgress this genomic region into elite chickpea genotype JG 11 were initiated using MABC approach as described by Varshney et al. (2013b). Introgression lines generated after three backcross and two rounds of selfing $\left(\mathrm{BC}_{3} \mathrm{~F}_{3}\right)$ showed improved performance with $12 \%$ (under rainfed) to $24 \%$ (under irrigated) higher yield. After multilocation field evaluation, 10 introgression lines have been identified as superior and are being sent for AICRP trial for release in India. Inspired by success of JG11+, efforts have already been initiated to introgress this genomic region in several other elite chickpea varieties. In addition, similar 
efforts to introgress the genomic region were also initiated by Indian Agricultural Research Institute (IARI, New Delhi) and Indian Institute of Pulse Research (IIPR, Kanpur) and their introgression lines are under field evaluation. Similar efforts were also undertaken for introgressing the $\mathrm{FW}$ and $\mathrm{AB}$ resistance in elite chickpea cultivar C 214 using MABC. Introgression lines developed in the background of $\mathrm{C} 214$ have shown enhanced resistance for FW and $\mathrm{AB}$ (Varshney et al. 2014c). Currently, efforts are underway to pyramid $\mathrm{FW}$ and $\mathrm{AB}$ resistance in same genotype of C 214 background through intercrossing of introgression lines.

In addition to MABC, ICRISAT also initiated efforts to deploy the GS in the chickpea breeding program. For this, a set of 320 elite chickpea lines was selected and genotyped using DArT markers. This set was phenotyped at Patancheru and New Delhi for two seasons for yield and yield-related traits. Phenotyping data along with genome-wide marker profile data was used with six statistical GS models to estimate the prediction accuracies (Roorkiwal et al. 2016).

\subsection{Conclusion}

Chickpea was earlier known as "orphan crop" because of limited availability of genomic resources, but recent efforts have transformed it to a genomic resource-rich crop. Last decade has witnessed tremendous growth in establishment of genomic resources for chickpea and utilization of these genomic resources in enhancing the chickpea productivity. Focus has never been limited to developing genomic resource, but to deployment of developed genetic resources in crop improvement programs leading to enhancement of chickpea production. Availability of whole genome sequence and different re-sequencing efforts has allowed the development of high-throughput genotyping platform, one such being Axiom ${ }^{\circledR}$ CicerSNP array (Roorkiwal et al. 2017). In order to deploy these genomic resources in chickpea breeding, MABC is being routinely used for developing superior varieties by targeting simple traits. Recently, GS has also gained momentum with its capability to target complex traits and ICRISAT has initiated deployment of GS in chickpea. As mentioned above, narrow genetic diversity is one of the major factors, restraining the efforts for enhancing the chickpea productivity. ICRISAT has also started toward developing the multi-parent advanced generation intercross (MAGIC) population for addressing the issue of narrow genetic diversity. Similarly, nested association mapping (NAM) population are also being developed. In summary, chickpea crop improvement is moving toward integrating modern genomics approach with existing breeding programs for enhancing chickpea yield.

\section{References}

Afonso-Grunz F, Molina C, Hoffmeier K, Rycak L, Kudapa H et al (2014) Genome-based analysis of the transcriptome from mature chickpea root nodules. Front Plant Sci 5:325

Ahmad E, Gaur PM, Slinkard AE (1992) Isozyme polymorphism and phylogenetic interpretations in the genus Cicer L. Theor Appl Genet 83:620-627

Ahmad F, Gaur PM, Croser J (2005) Chickpea (Cicer arietinum L.). In: Singh RJ, Jauhar PP (eds) Genetic resources, chromosome engineering, and crop improvement-grain legumes. vol 1. CRC Press, Boca Raton, pp 187-217

Bajaj D, Das S, Upadhyaya HD, Ranjan R, Badoni S et al (2015) A genome-wide combinatorial strategy dissects complex genetic architecture of seed coat color in chickpea. Front Plant Sci 6:979

Bakht J, Bano A, Dominy P (2006) The role of abscisic acid and low temperature in chickpea (Cicer arietinum) cold tolerance. II. Effects on plasma membrane structure and function. J Exp Bot 57:3707-3715

Banerjee H, Pai RA, Sharma RP (1999) Restriction fragment length polymorphism and random amplified polymorphic DNA analysis of chickpea accessions. Biologia Plant 42:197-208

Bharadwaj C, Chauhan SK, Yadav S, Satyavathi CT, Singh R et al (2011) Molecular marker-based linkage map of chickpea (Cicer arietinum) developed from desi $\times$ kabuli cross. Ind J Agric Sci 81:116-118

Buhariwalla HK, Jayashree B, Crouch JH (2005) ESTs from chickpea roots with putative roles in drought tolerance. BMC Plant Biology 5:16

Chen WJ, Zhu T (2004) Networks of transcription factors with roles in environmental stress response. Trends in Plant Sci 9:591-596. doi:10.1016/j.tplants.2004.10. 007 
Cho S, Kumar J, Shultz JL, Anupama K, Tefera F et al (2002) Mapping genes for double podding and other morphological trait in chickpea. Euphytica 125:285292

Choudhary S, Gaur R, Gupta S, Bhatia S (2012) EST-derived genic molecular markers: development and utilization for generating an advanced transcript map of chickpea. Theor Appl Genet 124:1449-1462

Cobos MJ, Fernández MJ, Rubio J, Kharrat M, Moreno MT et al (2005) A linkage map in chickpea (Cicer arietinum L.) in two populations from Kabuli $\times$ Desi crosses: location of a resistance gene for fusarium wilt race 0. Theor Appl Genet 110:13471353

Collard BCY, Pang ECK, Ades PK, Taylor PWJ (2003) Preliminary investigation of QTLs associated with seedling resistance to Ascochyta blight from Cicer echinospermum, a wild relative of chickpea. Theor Appl Genet 107:719-729

Croser JS, Ahmad F, Clarke HJ, Siddique KHM (2003) Utilisation of wild Cicer in chickpea improvementprogress, constraints, and prospects. Crop Pasture Sci 54:429-444

Deokar AA, Ramsay L, Sharpe AG, Diapari M, Sindhu A et al (2014) Genome wide SNP identification in chickpea for use in development of a high density genetic map and improvement of chickpea reference genome assembly. BMC Genomics 15:1

FAO (2014) http://www.fao.org/faostat/en/\#data/QC

Garg R, Patel RK, Tyagi AK, Jain M (2011a) De novo assembly of chickpea transcriptome using short reads for gene discovery and marker identification. DNA Res 18:53-63

Garg R, Patel RK, Jhanwar S, Priya P, Bhattacharjee A et al (2011b) Gene discovery and tissue-specific transcriptome analysis in chickpea with massively parallel pyrosequencing and web resource development. Plant Physiol 156:1661-1678

Gaur PM, Slinkard AE (1990) Genetic control and linkage relations of additional isozyme markers in chick-pea. Theor Appl Genet 80:648-656

Gaur PM, Stinkard AE (1990) Inheritance and linkage of isozyme coding genes in chickpea. J Heredity 81:455461

Gaur R, Sethy NK, Choudhary S, Shokeen B, Gupta V et al (2011) Advancing the STMS genomic resources for defining new locations on the intraspecific genetic linkage map of chickpea (Cicer arietinum L.). BMC Genomics 12:117

Gaur R, Jeena G, Shah N, Gupta S, Pradhan S et al (2015) High density linkage mapping of genomic and transcriptomic SNPs for synteny analysis and anchoring the genome sequence of chickpea. Sci Rep 5:13387

Gujaria N, Kumar A, Dauthal P, Dubey A, Hiremath P et al (2011) Development and use of genic molecular markers (GMMs) for construction of a transcript map of chickpea (Cicer arietinum L.). Theor Appl Genet 122:1577-1589

Gupta S, Kumar T, Verma S, Bharadwaj C, Bhatia S (2015) Development of gene-based markers for use in construction of the chickpea (Cicer arietinum L.) genetic linkage map and identification of QTLs associated with seed weight and plant height. Mol Biol Rep 42:1571-1580

Gupta S, Nawaz K, Parween S, Roy R, Sahu K, et al (2016) Draft genome sequence of Cicer reticulatum L., the wild progenitor of chickpea provides a resource for agronomic trait improvement. DNA Res. doi: 10 . 1093/dnares/dsw042

Hiremath PJ, Farmer A, Cannon SB, Woodward J, Kudapa H et al (2011) Large-scale transcriptome analysis in chickpea (Cicer arietinum L.), an orphan legume crop of the semi-arid tropics of Asia and Africa. Plant Biotechnol J 9:922-931

Hiremath PJ, Kumar A, Penmetsa RV, Farmer A, Schlueter JA et al (2012) Large-scale development of cost-effective SNP marker assays for diversity assessment and genetic mapping in chickpea and comparative mapping in legumes. Plant Biotechnol J 10:716732

Hüttel B, Winter P, Weising K, Choumane W, Weigand F et al (1999) Sequence-tagged microsatellite site markers for chickpea (Cicer arietinum L.). Genome 42:210-217

Iruela M, Rubio J, Cubero JI, Gil J, Millán T (2002) Phylogenetic analysis in the genus Cicer and cultivated chickpea using RAPD and ISSR markers. Theor Appl Genet 104:643-651

Jaganathan D, Thudi M, Kale S, Azam S, Roorkiwal M et al (2015) Genotyping-by-sequencing based intra-specific genetic map refines a "QTL-hotspot" region for drought tolerance in chickpea. Mol Genet Genomics 290:559-571

Jain M, Misra G, Patel RK, Priya P, Jhanwar S et al (2013) A draft genome sequence of the pulse crop chickpea (Cicer arietinum L.). Plant J 74:715-729

Jamalabadi JG, Saidi A, Karami E, Kharkesh M, Talebi R (2013) Molecular mapping and characterization of genes governing time to flowering, seed weight, and plant height in an intraspecific genetic linkage map of chickpea (Cicer arietinum). Biochem Genet 51:387-397

Jingade P, Ravikumar RL (2015) Development of molecular map and identification of QTLs linked to Fusarium wilt resistance in chickpea. J Genet 94:723-729

Kale SM, Jaganathan D, Ruperao P, Chen C, Punna R, et al (2015) Prioritization of candidate genes in "QTL-hotspot" region for drought tolerance in chickpea (Cicer arietinum L.). Sci Rep 5, 15296

Karami E, Talebi R, Kharkesh M, Saidi A (2015) A linkage map of chickpea (Cicer arietinum L.) based on population from ILC3279 $\times$ ILC588 crosses: location of genes for time to flowering, seed size and plant height. Genetika 47:253-263

Kazan K, Muehlbauer FJ (1991) Allozyme variation and phylogeny in annual species of Cicer (Leguminosae). Plant Syst Evol 175:11-21

Kazan KMFJ, Muehlbauer FJ, Weeden NE, Ladizinsky G (1993) Inheritance and linkage relationships of morphological and isozyme loci in chickpea (Cicer arietinum L.). Theor Appl Genet 86:417-426 
Khajuria YP, Saxena MS, Gaur R, Chattopadhyay D, Jain $\mathrm{M}$ et al (2015) Development and Integration of Genome-Wide Polymorphic Microsatellite Markers onto a Reference Linkage Map for Constructing a High-Density Genetic Map of Chickpea. PLoS ONE 10:e0125583

Kottapalli P, Gaur PM, Katiyar SK, Crouch JH, Buhariwalla HK et al (2009) Mapping and validation of QTLs for resistance to an Indian isolate of Ascochyta blight pathogen in chickpea. Euphytica 165:79-88

Kudapa K, Azam S, Sharpe AG, Taran B, Li R et al (2014) Comprehensive transcriptome assembly of chickpea (Cicer arietinum L.) using Sanger and next generation sequencing platforms: development and applications. PLoS ONE 9:e86039

Kujur A, Bajaj D, Upadhyaya HD, Das S, Ranjan R et al (2015) Employing genome-wide SNP discovery and genotyping strategy to extrapolate the natural allelic diversity and domestication patterns in chickpea. Front Plant Sci 6:162

Kusmenoglu I, Muehlbauer FJ, Kazan K (1992) Inheritance of isozyme variation in ascochyta blight-resistant chickpea lines. Crop Sci 32:121-127

Labdi M, Robertson LD, Singh KB, Charrier A (1996) Genetic diversity and phylogenetic relationships among the annual Cicer species as revealed by isozyme polymorphism. Euphytica $88: 181-188$

Lichtenzveig J, Scheuring C, Dodge J, Abbo S, Zhang HB (2005) Construction of BAC and BIBAC libraries and their application for generation of SSR markers for genome analysis of chickpea (Cicer arietinum L.). Theor Appl Genet 110:492-510

McCouch S, Baute GJ, Bradeen J, Bramel P, Bretting PK et al (2013) Agriculture: feeding the future. Nature 499:23-24

Meuwissen THE, Hayes BJ, Goddard ME (2001) Prediction of total genetic value using genome wide dense marker maps. Genetics 157:1819-1829

Millan T, Winter P, Jüngling R, Gil J, Rubio J et al (2010) A consensus genetic map of chickpea (Cicer arietinum L.) based on 10 mapping populations. Euphytica 175:175-189

Mir RR, Zaman-Allah M, Sreenivasulu N, Trethowan R, Varshney RK (2012) Integrated genomics, physiology and breeding approaches for improving drought tolerance in crops. Theor Appl Genet 125:625-645

Nayak SN, Zhu H, Varghese N, Datta S, Choi HK et al (2010) Integration of novel SSR and gene-based SNP marker loci in the chickpea genetic map and establishment of new anchor points with Medicago truncatula genome. Theor Appl Genet 120:1415-1441

Neumann K, Kobiljski B, Denčić S, Varshney RK, Börner A (2011) Genome-wide association mapping: a case study in bread wheat (Triticum aestivum L.). Mol Breed 27:37-58

Nguyen TT, Taylor PWJ, Redden RJ, Ford R (2004) Genetic diversity estimates in Cicer using AFLP analysis. Plant Breed 123:173-179

Oram RN, Shaikh MAQ, Zaman KMS, Brown AHD (1987) Isozyme similarity and genetic differences in morphology between Hyprosola, A high yielding, high protein mutant of chickpea (Cicer arietinum L.) and its parental cultivar. Env Exp Bot 27:455-462

Palomino C, Fernández-Romero MD, Rubio J, Torres A, Moreno MT et al (2009) Integration of new CAPS and dCAPS-RGA markers into a composite chickpea genetic map and their association with disease resistance. Theor Appl Genet 118:671-682

Pandey MK, Roorkiwal M, Singh VK, Ramalingam A, Kudapa $\mathrm{H}$ et al (2016) Emerging genomic tools for legume breeding: current status and future prospects. Front Plant Sci 7:455. doi:10.3389/fpls.2016.00455

Parween S, Nawaz K, Roy R, Pole AK, Suresh BV, et al (2015) An advanced draft genome assembly of a desi type chickpea (Cicer arietinum L.). Sci Rep 5:12806.

Pfaff T, Kahl G (2003) Mapping of gene-specific markers on the genetic map of chickpea (Cicer arietinum L.). Mol Genet Genomics 269:243-251

Pushpavalli R, Krishnamurthy L, Thudi M, Gaur PM, Rao MV et al (2015) Two key genomic regions harbour QTLs for salinity tolerance in ICCV $2 \times \mathrm{JG}$ 11 derived chickpea (Cicer arietinum L.) recombinant inbred lines. BMC Plant Biol 15:124

Radhika P, Gowda SJM, Kadoo NY, Mhase LB, Jamadagni BM et al (2007) Development of an integrated intraspecific map of chickpea (Cicer arietinum L.) using two recombinant inbred line populations. Theor Appl Genet 115:209-216

Roorkiwal M, Jain A, Kale SM, Doddamani D, Chitikineni A et al (2017) Development and evaluation of high density SNP array (Axiom®CicerSNP Array) for high resolution genetic mapping and breeding applications in chickpea. Plant Biotechnol J. doi:10.1111/ pbi. 12836

Roorkiwal M, Sawargaonkar SL, Chitikineni A, Thudi M, Saxena RK et al (2013) Single nucleotide polymorphism genotyping for breeding and genetics applications in chickpea and pigeonpea using the BeadXpress platform. Plant Genome 6:2

Roorkiwal M, Nayak SN, Thudi M, Upadhyaya HD, Brunel D et al (2014a) Allele diversity for abiotic stress responsive candidate genes in chickpea reference set using gene based SNP markers. Front Plant Sci 5:248

Roorkiwal M, Von Wettberg EJ, Upadhyaya HD, Warschefsky E, Rathore A et al (2014b) Exploring germplasm diversity to understand the domestication process in Cicer spp. using SNP and DArT markers. PLoS ONE 9:e102016

Roorkiwal M, Rathore A, Das RR, Singh MK, Jain A et al (2016) Genome-enabled prediction models for yield related traits in chickpea. Front Plant Sci 7:1666

Ruelland E, Cantrel C, Gawer M, Kader JC, Zachowski A (2002) Activation of phospholipases C and D is an early response to a cold exposure in Arabidopsis suspension cells. Plant Physiol 130:999-1007

Ruperao P, Chan CK, Azam S, Karafiátová M, Hayashi S et al (2014) A chromosomal genomics approach to assess and validate the desi and kabuli draft chickpea genome assemblies. Plant Biotechnol J 12:778-786 
Sabbavarapu MM, Sharma M, Chamarthi SK, Swapna N, Rathore A et al (2013) Molecular mapping of QTLs for resistance to Fusarium wilt (race 1) and Ascochyta blight in chickpea (Cicer arietinum L.). Euphytica 193:121-133

Sant VJ, Patankar AG, Sarode ND, Mhase LB, Sainani MN et al (1999) Potential of DNA markers in detecting divergence and in analysing heterosis in Indian elite chickpea cultivars. Theor Appl Genet 98:1217-1225

Santra DK, Tekeoglu M, Ratnaparkhe M, Kaiser WJ, Muehlbauer FJ (2000) Identification and mapping of QTLs conferring resistance to ascochyta blight in chickpea. Crop Sci 40:1606-1612

Serret MD, Udupa SM, Weigand F (1997) Assessment of genetic diversity of cultivated chickpea using microsatellite-derived RFLP markers; Implications for origin. Plant Breed 116:573-578

Shan F, Clarke HC, Plummer JA, Yan G, Siddique KHM (2005) Geographical patterns of genetic variation in the world collections of wild annual Cicer characterized by amplified fragment length polymorphisms. Theor Appl Genet 110:381-391

Simon CJ, Muehibauer FJ (1997) Construction of a chickpea linkage map and its comparison with maps of pea and lentil. J Heredity 88:115-119

Singh U (1985) Nutritional quality of chickpea (Cicer arietinum L.): current status and future research needs. Plant Foods for Human Nutr 35:339-351

Singh KB, Omar M, Saxena MC, Johansen C (1997) Screening for drought resistance in spring chickpea in the Mediterranean region. J Agronomy Crop Sci 178:227-235

Singh R, Prasad CD, Singhal V, Randhawa GJ (2003) Assessment of genetic diversity in chickpea cultivars using RAPD, AFLP and STMS markers. J Genet Breed 57:165-174

Singh R, Sharma P, Varshney RK, Sharma SK, Singh NK (2008) Chickpea improvement: Role of wild species and genetic markers. Biotechnol Genet Eng Rev 25:267-314

Singh VK, Garg R, Jain M (2013) A global view of transcriptome dynamics during flower development in chickpea by deep sequencing. Plant Biotechnol 11:691-701

Srivastava R, Singh M, Bajaj D, Parida SK (2016) A high-resolution InDel (Insertion-Deletion) markers-anchored consensus genetic map identifies major QTLs governing pod number and seed yield in chickpea. Front Plant Sci 7:1362

Stephens A, Lombardi M, Cogan NO, Forster JW, Hobson K et al (2013) Genetic marker discovery, intraspecific linkage map construction and quantitative trait locus analysis of Ascochyta blight resistance in chickpea (Cicer arietinum L.). Mol Breed 33:297-313

Sudupak MA, Akkaya MS, Kence A (2004) Genetic relationships among perennial and annual Cicer species growing in Turkey assessed by AFLP fingerprinting. Theor Appl Genet 108:937-944
Talebi R, Naji AM, Fayaz F (2008) Geographical patterns of genetic diversity in cultivated chickpea (Cicer arietinum L.) characterized by amplified fragment length polymorphism. Plant Soil Environ 54:447-452

Tayyar RI, Waines JG (1996) Genetic relationships among annual species of Cicer (Fabaceae) using isozyme variation. Theor Appl Genet 92:245-254

Tekeoglu M, Rajesh PN, Muehlbauer FJ (2002) Integration of sequence tagged microsatellite sites to the chickpea genetic map. Theor Appl Genet 105:847854

Thudi M, Bohra A, Nayak SN, Varghese N, Shah TM et al (2011) Novel SSR markers from BAC-end sequences, DArT arrays and a comprehensive genetic map with 1,291 marker loci for chickpea (Cicer arietinum L.). PLoS ONE 6:e27275

Thudi M, Li Y, Jackson SA, May GD, Varshney RK (2012) Current state-of-art of sequencing technologies for plant genomics research. Brief Funct Genomics 11:3-11

Thudi M, Upadhyaya HD, Rathore A, Gaur PM, Krishnamurthy L et al (2014) Genetic dissection of drought and heat tolerance in chickpea through genome-wide and candidate gene-based association mapping approaches. PLoS ONE 9:e96758

Thudi M, Chitikineni A, Liu X, He W, Roorkiwal M, et al (2016) Recent breeding programs enhanced genetic diversity in both desi and kabuli varieties of chickpea (Cicer arietinum L.). Sci. Rep. 6:38636.

Tullu A, Muehlbauer FJ, Simon CJ, Mayer MS, Kumar J et al (1998) Inheritance and linkage of a gene for resistance to race 4 of fusarium wilt and RAPD markers in chickpea. Euphytica 102:227-232

Turner NC, Begg JE (1978) Responses of pasture plants to water deficits. In: Wilson JR (ed) Plant relations in pastures, CSIRO Melbourne, pp. 50-66.

Udupa SM, Sharma A, Sharma RP, Pai RA (1993) Narrow genetic variability in Cicer arietinum L. as revealed by RFLP analysis. J Plant Biochem Biotechnol 2:83-86

Van Rheenen HA (1992) Biotechnology and chickpea breeding. Int Chickpea Newslett 26:14-17

Varshney RK (2016) Exciting journey of 10 years from genomes to fields and markets: Some success stories of genomics-assisted breeding in chickpea, pigeonpea and groundnut. Plant Sci 242:98-107

Varshney RK, Graner A, Sorrells ME (2005) Genomics-assisted breeding for crop improvement. Trends Plant Sci 10:621-630

Varshney RK, Chabane K, Hendre PS, Aggarwal RK, Graner A (2007a) Comparative assessment of EST-SSR, EST-SNP and AFLP markers for evaluation of genetic diversity and conservation of genetic resources using wild, cultivated and elite barleys. Plant Sci 173:638-649

Varshney RK, Nayak S, Jayashree B, Eshwar K, Upadhyaya $\mathrm{HD}$ et al (2007b) Development of cost-effective SNP assays for chickpea genome analysis and breeding. J SAT Agric Res 3(1):1-3 
Varshney RK, Hiremath PJ, Lekha P, Kashiwagi J, Balaji $\mathrm{J}$ et al (2009) A comprehensive resource of drought- and salinity- responsive ESTs for gene discovery and marker development in chickpea (Cicer arietinum L.). BMC Genomics 10:523

Varshney RK, Ribaut JM, Buckler ES, Tuberosa R, Rafalski JA et al (2012a) Can genomics boost productivity of orphan crops? Nat Biotechnol 30:1172-1176

Varshney RK, Kudapa H, Roorkiwal M, Thudi M, Pandey MK et al (2012b) Advances in genetics and molecular breeding of three legume crops of semi-arid tropics using next-generation sequencing and high-throughput genotyping technologies. J Biosci 37:811-820

Varshney RK, Song C, Saxena RK, Azam S, Yu S et al (2013a) Draft genome sequence of chickpea (Cicer arietinum) provides a resource for trait improvement. Nat Biotechnol 31:240-246

Varshney RK, Gaur PM, Chamarthi SK, Krishnamurthy L, Tripathi S et al (2013b) Fast-track introgression of "QTL-Hotspot" for root traits and other drought tolerance traits in JG 11, an elite and leading variety of chickpea. Plant Genome 6:3. doi:10.3835/ plantgenome2013.07.0022

Varshney RK, Thudi M, Nayak SN, Gaur PM, Kashiwagi J et al (2014a) Genetic dissection of drought tolerance in chickpea (Cicer arietinum L.). Theor Appl Genet 127:445-462

Varshney RK, Mir RR, Bhatia S, Thudi M, Hu Y et al (2014b) Integrated physical, genetic and genome map of chickpea (Cicer arietinum L.). Funct Integrative Genomics 14:59-73

Varshney RK, Mohan SM, Gaur PM, Chamarthi SK, Singh VK et al (2014c) Marker-assisted backcrossing to introgress resistance to Fusarium wilt $(\mathrm{FW})$ race 1 and Ascochyta blight (AB) in C 214, an elite cultivar of chickpea. Plant Genome 7:1. doi:10.3835/ plantgenome2013.10.0035

Varshney RK, Kudapa H, Pazhamala L, Chitikineni A, Thudi $M$ et al (2015) Translational genomics in agriculture: some examples in grain legumes. CRC Crit. Rev Plant Sci 34:169-194

Verma S, Gupta S, Bandhiwal N, Kumar T, Bharadwaj C, et al (2015) High-density linkage map construction and mapping of seed trait QTLs in chickpea (Cicer arietinum L.) using Genotyping-by-Sequencing (GBS). Sci Rep 5:17512

Vos P, Hogers R, Bleeker M, Reijans M, Van de Lee T et al (1995) AFLP: a new technique for DNA fingerprinting. Nucleic Acids Res 23:4407-4414

Winter P, Pfaff T, Udupa SM, Hüttel B, Sharma PC et al (1999) Characterization and mapping of sequence-tagged microsatellite sites in the chickpea (Cicer arietinum L.) genome. Mol Gen Genet 262:90101

Winter P, Benko-Iseppon AM, Hüttel B, Ratnaparkhe M, Tullu A et al (2000) A linkage map of the chickpea (Cicer arietinum L.) genome based on recombinant inbred lines from a $C$. arietinum $\times C$. reticulatum cross; localization of resistance genes for fusarium wilt races 4 and 5. Theor Appl Genet 101:1155-1163 